\title{
SOME NOTEWORTHY FINDINGS OF APHYLLOPHOROID FUNGI IN THE NORTH OF EASTERN FENNOSCANDIA (MURMANSK REGION, RUSSIA)
}

\author{
Yuliia R. Khimich ${ }^{1 *}$, Anton G. ShIRYAeV ${ }^{2}$, Sergey V. Volobuev ${ }^{3}$ \\ ${ }^{1}$ Institute of North Industrial Ecology Problems, Kola Science Centre, Russian Academy of Sciences, \\ Akademgorodok Str.14a, 184209 Apatity, Murmansk Region, Russia \\ ${ }^{2}$ Institute of Plant \& Animal Ecology (IPAE), Ural Branch of the Russian Academy of Sciences (UrB RAS), \\ 8th March Str. 202/3, 620144 Ekaterinburg, Russia \\ ${ }^{3}$ Komarov Botanical Institute of the Russian Academy of Sciences, Professor Popov Str. 2, \\ 197376 St Petersburg, Russia \\ *Corresponding author. E-mail: ukhim@inbox.ru
}

\begin{abstract}
Khimich Yu.R., Shiryaev A.G., Volobuev S.V., 2020: Some noteworthy findings of Aphyllophoroid fungi in the north of Eastern Fennoscandia (Murmansk Region, Russia). - Botanica, 26(1): 49-60.

Twenty-eight noteworthy species of aphyllophoroid fungi were recorded in the Murmansk Region (north-eastern Fennoscandia, Russia). Twenty-one species were reported for the first time in the region: Ceratellopsis corneri, Clavaria amoenoides, C. flavipes, Clavulinopsis umbrinella, Fibulomyces mutabilis, Hydnomerulius pinastri, Hyphoderma sibiricum, Hypochnicium albostramineum, Lentaria afflata, L. micheneri, Peniophorella pallida, Piloderma lanatum, Postia rennyi, Pseudotomentella umbrina, Ramariopsis crocea, $R$. tenuicula, Sarcodon scabrosus, Sistotrema diademiferum, Typhula curvispora, T. pachypus and T. struthiopteridis. Seven species are second and third records in the forest tundra and northern boreal zone: Ceratellopsis sagittiformis, Odontia fibrosa, Phaeoclavulina flaccida, Pterula sclerotiicola, Ramariopsis tenuiramosa, Tomentellopsis echinospora and Tulasnella allantospora.
\end{abstract}

Keywords: anthropogenic impact, climate change, CRIS, forest-tundra, fungal distribution, GBIF, new records, subarctic.

\section{INTRODUCTION}

Eastern Fennoscandia includes Finland and some territories in the north-western part of Russia (Murmansk Region, Republic of Karelia, smaller parts of Arkhangelsk and Leningrad Regions). The Murmansk Region is situated almost entirely north of the Arctic Circle, but is influenced by the warm Gulf Stream. The location of the region contributed to the development of boreal forests (northern boreal zone), and the climatic conditions allowed forest vegetation to spread northward (RAMENSKAYA, 1983). Mycological studies in the northern part of eastern Fennoscandia are important for understanding the species distribution, changes in species ranges under the influence of climate change (Dahlberg \& Bultmann, 2013). Fungi have been well studied in Finland, although the northern part has been studied less than the southern. In Finland, over the past ten years 27 species of aphyllophoroid fungi occurring mainly in the south of the country have been recorded in the northern boreal zone and the frequency of observations of such a rare fungus as Sarcosoma globosum has increased in the recent years (KUNTTU et al., 2011, 2012, 2013, 2014, 2015, 2016, 2018; KotiRAnTA \& Shiryaev, 2013; OHENOJA et al., 2013).

Over the same period, extensive mycological studies have been conducted in the Murmansk Region (IsAEVA \& KHIMICH, 2011), as a result the northernmost 
locations in eastern Fennoscandia have been recorded for some species (КнімісH et al., 2015, 2017; BolshAKOv et al., 2016, 2018; Кнімісн \& Zмітrovich, 2017, 2019; SvetasheVA et al., 2017). Thus, in the Murmansk Region, there is a similar tendency for the northward spreading of certain species of fungi. Further study of mycobiota in the Murmansk Region to assess the impact of climate change is very relevant. In such an industrially developed region, urbanized and anthropogenically transformed areas can become a source of spread for specific species of fungi, and, therefore, require special attention. This paper presents new records of noteworthy aphyllophoroid fungi in the Murmansk Region.

\section{MATERIALS AND METHODS}

\section{Study area}

The Murmansk Region is located on the northeastern boundary of Fennoscandia, the north-west of Russia. The regional centre is Murmansk city. The area of the region is $145,000 \mathrm{~km}^{2}$. The relief is hilly, with Khibiny and Lovozero mountains in the central part of the region rising to as high as $1200 \mathrm{~m}$ above the sea level (a.s.1.), and more flat in the east. The climate is predominantly affected by the North Atlantic and the Polar Arctic masses (Alisov, 1969), but MoEN (1999) has defined this area as slightly continental. Because of the Gulf Stream, winter temperatures are relatively mild. The climate is characterized by relatively mild winters and cold, short summers; short freezing periods may be observed in any of the summer months, except July (YAKOVLEV, 1961). January is the coldest month and July is the warmest. Mean annual precipitation is relatively low, $550-600 \mathrm{~mm}$; much of it falls on the summer months. The snow usually covers the ground from mid-October to late May-June; both its distribution and melting time in the mountains depend on the topography.

The region is located in the northern boreal zone according to Aнті et al. (1968). Two vegetation zones are represented in the Murmansk Region - tundra and taiga, the northern forest border or limit of which is formed by birch stands, as is typical for areas with an oceanic and suboceanic climate. The region is mainly covered by pine and spruce northern boreal forests. The forest-tundra stretches from north-west to south-east in a belt 20 to $100 \mathrm{~km}$ wide (or more). In all mountain areas, vertical vegetation zones are distinguished. The foothills are dominated by forests. Higher up, at an altitude of 300-450 m a.s.l., stunted birch forest covers steeper slopes in wedges. The upper part of the slopes (over 400-450 m a.s.l.) and peaks are covered by mountain tundra with vast rock fields, detritus and bedrock outcrops.

\section{Data sampling}

The observations presented in this paper were mainly made in 2018 and 2019 (Kirovsk, Kola and Pechenga Districts and Murmansk), but include some older records from Kandalaksha District as well (Fig. 1). The surveys were carried out both in natural forests and in urban areas (Murmansk and Kirovsk cities).

The material was microscopically examined using standard methods and chemicals (KOH, Melzer's reagent, etc.). The cited specimens are deposited at the Herbaria of the Institute of the North Industrial Ecology Problems (INEP) and Komarov Botanical Institute of the Russian Academy of Sciences (LE). Some specimens of clavarioid fungi collected by A.G. Shiryaev are listed in the author's personal database (AGS) at the Herbarium of the Institute of Plant and Animal Ecology of the Ural Branch of the Russian Academy of Sciences (Ekaterinburg, SVER). Information about the specimens from INEP will be available in CRIS (Cryptogamic Russian Information System, http:// kpabg.ru/cris) (MeLEKHIN et al., 2019).

The taxa below are listed in alphabetical order. The species nomenclature generally follows Index Fungorum (2019). Abbreviations denoting collectors/identifiers are as follows: ASh - A.G. Shiryaev, EB - E.A. Borovichev, IZ - I.V. Zmitrovich, SV S.V. Volobuev, YuK - Yu.R. Khimich. Species newly found in the Murmansk Region are marked with an asterisk $(*)$.

\section{LIST OF SPECIES}

${ }^{*}$ Ceratellopsis corneri Berthier - Pechenga Disrict, the Pasvik State Nature Reserve, surrounds of Varlama Island, $69.14017^{\circ} \mathrm{N}, 29.2527^{\circ} \mathrm{E}$, on fallen decayed twigs of Betula and Pinus in the pine-birch dominated forest with an admixture of Salix and Sorbus, among mosses, 6 September 2018, coll. and id. ASh (AGS 831-18). Added records: Russian Karelia, Pryazhinsky District, surrounds of Kolatselga village, $61.6606^{\circ} \mathrm{N}$, $32.2387^{\circ} \mathrm{E}$, on a rotten branch of pine, coll. O. V. Izva- 


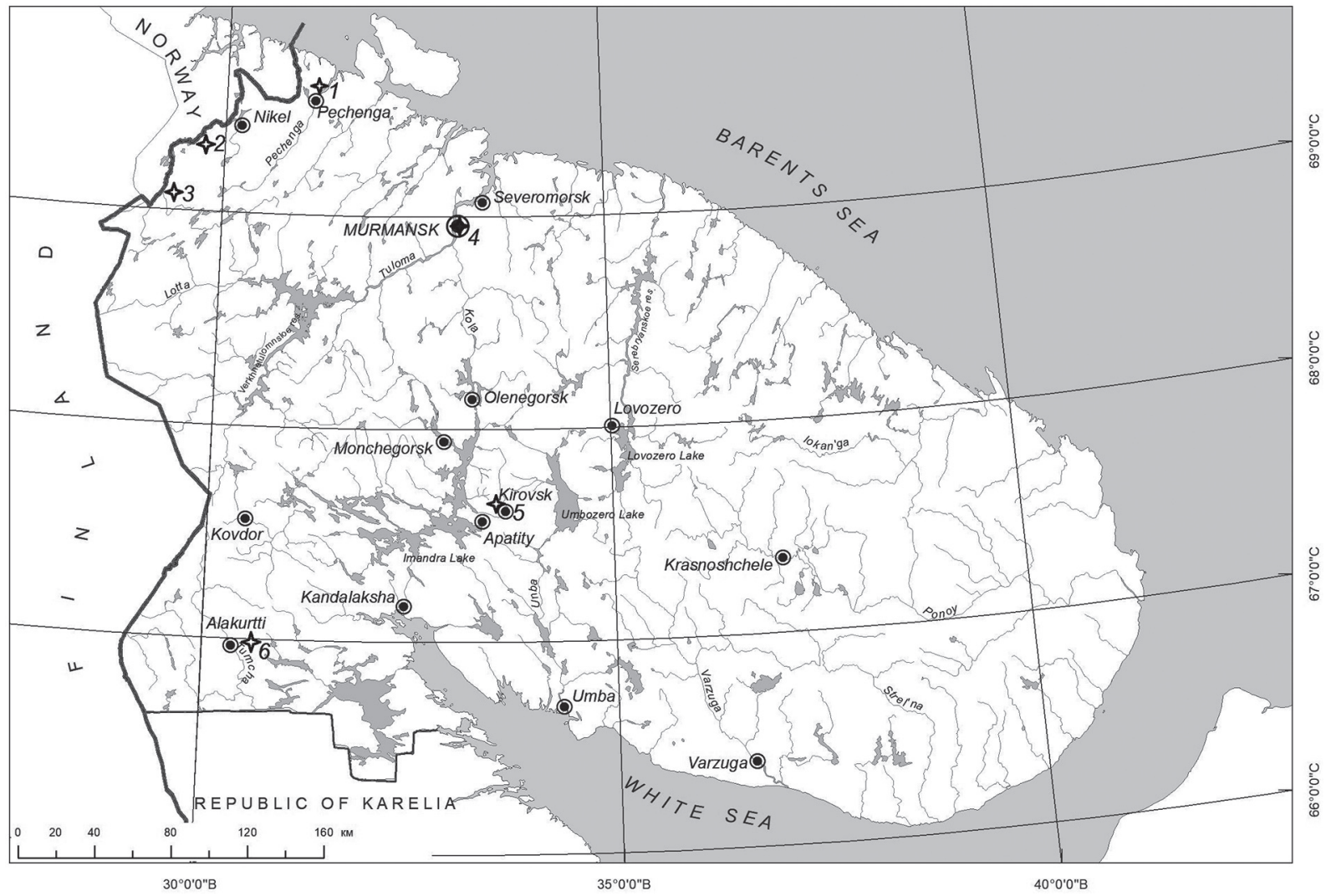

Fig. 1. Map of the Murmansk Region with study areas: 1 - the vicinity of Liinakhamari, Trifanovo and Sputnik settlements; 2 the Pasvik State Nature Reserve; 3 - downstream of the Nautsi River; 4 - Murmansk and the neighbourhood of Pajyavr Lake; 5 - Khibiny Mts and Polar-Alpine Botanical Garden-Institute; 6 - the vicinity of Alakurtti settlement

rina, id. ASh, 18 September 2011 (SVER 79758). Finland, Kainuu, Hiidenportti National Park, $63.8659^{\circ} \mathrm{N}$, $29.0031^{\circ} \mathrm{E}$, coniferous spruce-pine-dominated forest, at the forest-meadow boundary, on a fallen branch of Picea in a layer of moss, 29 September 2016, coll. A. Kirs, id. ASh (SVER 79486).

Distribution in Fennoscandia: a little-known species, probably widespread in Europe, but due to small size of basidiomata, it is rarely collected or is confused with Pterula gracilis or species of the genus Typhula. A genetic study of all available specimens of this species is needed. To date, in the scientific literature and databases, there is no other information about the findings of this species in Fennoscandia. Thus, only three locations of this species are known in Fennoscandia.

Ceratellopsis sagittiformis (Pat.) Corner - 1) Pechenga District, the Pasvik State Nature Reserve, $69.35866^{\circ} \mathrm{N}, 29.79143^{\circ} \mathrm{E}$, mixed pine-dominated shrub-green moss forest with a birch admixture, on dead grasses and mosses, 5 September 2018, coll. and id. ASh (AGS 801-18); 2) Kirovsk District, Khibiny Mts., moraine at the foot of Kukisvumchorr Mt. in the valley of Maly Vud yavr Lake, nearby Umetsky Pole, in the vicinity of a pumping station, $67.658213^{\circ} \mathrm{N}$, on mosses, $33.670991^{\circ} \mathrm{E}, 13$ September 2018, coll. and id. ASh (INEP 2124).

Distribution in Fennoscandia: sporadically, mostly in the southern Fennoscandia (KotIRANTA et al., 2009; GBIF, 2019). In Finland, there is a single known find of this species in the southern boreal zone (Kotiranta et al., 2009). In Norway, three localities of the fungus are known in the south of the country (GBIF, 2019). This species has not yet been found in Russian Karelia. The locality of our collection in the Murmansk Region (Pechenga District) is the northernmost in Fennoscandia. Earlier, in the Murmansk Region, C. sagittiformis has been observed in the Lapland State Nature Reserve (Кнгмісн et al., 2017). 
"Clavaria amoenoides Corner, K.S. Thind et Anand - Kirovsk District, Khibiny Mts., moraine at the foot of Kukisvumchorr Mt. in the valley of Maly Vud yavr Lake, $67.665225^{\circ} \mathrm{N}, 33.657106^{\circ} \mathrm{E}$, birch shrub-green moss forest, on the soil among mosses and grasses, 13 September 2018, coll. and id. ASh (AGS 895-18).

Distribution in Fennoscandia: widespread (KотIRANTA et al., 2009; GBIF, 2019), but most of the specimens have been collected in the southern and western parts of Fennoscandia, with only a few observations in the eastern part. In Russian Karelia, it has recently been found in the middle boreal zone in the Kivach State Nature Reserve (Shiryaev \& Ruokolainen, 2017). Previously, this species had been considered rare in Finland (KotIRANTA et al., 2009), but according to the latest data, it is quite widespread throughout the country and is spreading north into the northern boreal zone (KunTtu et al., 2016, 2018). However, this fungus has been observed in the Norwegian Finnmark County at the latitudes of $69^{\circ} \mathrm{N}$ (https://www.gbif.org/ occurrence/128275319) and $70^{\circ} \mathrm{N}$ (https://www.gbif. org/occurrence/1824443894).

${ }^{*}$ Clavaria flavipes Pers. - 1) Pechenga District, in the neighbourhood of Liinakhamari settlement, $69.632472^{\circ} \mathrm{N}, 31.312528^{\circ} \mathrm{E}$, on the soil in thickets of deciduous trees at the roadside, 7 September 2018, coll. YuK, id. ASh (INEP 2125); 2) Kirovsk District, Polar-Alpine Botanical Garden Institute, $67.648113^{\circ} \mathrm{N}$, $33.669761^{\circ} \mathrm{E}$, on a trail in the nursery-garden, on the soil, 9 September 2018, coll. YuK, id. ASh (INEP 2379); 3) Kirovsk District, Khibiny Mts., the southwest slope of the Poachvumchorr Ridge, $67.672222^{\circ} \mathrm{N}$, $33.623^{\circ} \mathrm{E}$, birch forest, fern-covered ravine, on the soil, 10 September 2019, coll. YuK, id. ASh (INEP 2439).

Distribution in Fennoscandia: widespread in the southern and central parts (GBIF, 2019), our findings are the northernmost in Fennoscandia. In Sweden, it is classified as Vulnerable and is found mainly in the south, with the northernmost observation in Lule Lappmark, Kvarnbäcken $\left(66.47166^{\circ} \mathrm{N}, 20.62867^{\circ} \mathrm{E}\right)$ (https://www.gbif.org/occurrence/849909903) (ARTFAKTA..., 2019). In Finland, it had previously been known from two locations in the south and considered quite rare, but in 2015 it was recorded in the middle and northern boreal zones (KunTtu et al., 2016). In the north of Norway, the fungus has not yet been registered (ARTSDATABANKEN, 2019); it is found in the south of the country only: Nordland, Forsheim, Vefsn (https://www.gbif.org/occurrence/1229534955). Recently, this species has been found in Russian Karelia, in the middle boreal zone (SHIRYAEV \& Ruokolainen, 2017).

${ }^{*}$ Clavulinopsis umbrinella (Sacc.) Corner - Kirovsk District, Khibiny Mts., 1) moraine at the foot of Kukisvumchorr Mt. in the valley of Maly Vud yavr Lake, $67.665225^{\circ} \mathrm{N}, 33.657106^{\circ} \mathrm{E}$, alpine timberline, birch shrub-green moss forest, on the rotten litter under ferns Athyrium distentifolium Tausch ex Opiz, 13 September 2018, coll. YuK, id. ASh (INEP 2377), ibid., coll. and id. ASh (AGS 890-18); 2) Yuzhnoe Skvoznoe Gorge, $67.598917^{\circ} \mathrm{N}, 33.595417^{\circ} \mathrm{E}$, timberline, patch of moss near fern thickets (A. distentifolium), on the soil, 11 September 2019, coll. YuK, id. YuK \& ASh (INEP 2438).

Distribution in Fennoscandia: widespread, but relatively rare. In Norway, Sweden and Finland, this species is considered Near Threatened and is found mainly in the south (ARTSDATABANKen, 2019; ARTFAKTA..., 2019; KоTIRANTA et al., 2009), rarely at a latitude of $65^{\circ} \mathrm{N}$. In Norway, it has been collected in Troms, Lenvik: Senja familiepark, Gressmyrbotn, $69.2872^{\circ} \mathrm{N}, 17.8948^{\circ} \mathrm{E}$ (https://www.gbif.org/ occurrence/1252407517). This fungus has not yet been observed in Russian Karelia.

*Fibulomyces mutabilis (Bres.) Jülich - Pechenga District, the Pasvik State Nature Reserve, $69.35866^{\circ} \mathrm{N}$, $29.79143^{\circ} \mathrm{E}$, pine shrub-green moss forest with a birch admixture, on a fallen trunk of Betula pubescens, 5 September 2018, coll. and id. SV (LE 314101).

Distribution in Fennoscandia: a widespread species of boreal fungi. This species is found in the middle and northern boreal zone of Russian Karelia (Bondartseva et al., 2001; Krutov et al., 2014), and in the south and north of Finland and Norway (KотIRANTA et al., 2009; ArtSDATABANKEn, 2019). There is only one observation in Norway at a latitude of $69^{\circ} \mathrm{N}$ (https://www.gbif.org/occurrence/1324364139).

${ }^{*}$ Hydnomerulius pinastri (Fr.) Jarosch et Besl Pechenga District, in the neighbourhood of Trifanovo settlement, on the shore of Pechenga Bay, $69.595306^{\circ} \mathrm{N}, 31.280056^{\circ} \mathrm{E}$, on a burnt coniferous 
log, the remains of an old pier, 7 September 2018, coll. YuK, id. IZ \& YuK (INEP 2097, 2128); ibidem, coll. and id. SV (LE 314170).

Distribution in Fennoscandia: a widespread species, but probably rare in the northern boreal zone. Our record is the northernmost in Fennoscandia. In Russian Karelia, Finland and Norway, this species is found in the south (RUOKOLAINEN \& KotKova, 2016a; Kotiranta et al., 2009; Artsdatabanken, 2019), although in Sweden, it is quite common and the northernmost find is at $66^{\circ} \mathrm{N}$ (GBIF, 2019). The fungus prefers anthropogenically modified wood such as building materials, buildings, greenhouses, cellars, logging waste (Bondartseva \& Parmasto, 1986; Kotiranta et al., 2009; Ruokolainen \& Kotkova, 2016a), but is also found in the natural environment.

${ }^{*}$ Hyphoderma sibiricum (Parmasto) J. Erikss. et Å. Strid - Kirovsk District, Khibiny Mts., moraine at the foot of Kukisvumchorr Mt. in the valley of Maly Vud yavr Lake, $67.665225^{\circ} \mathrm{N}, 33.657106^{\circ} \mathrm{E}$, birch shrub-green moss forest, on an uprooted juniper, 13 September 2018, coll. YuK, id. YuK \& IZ (INEP 2378).

Distribution in Fennoscandia: quite widespread in Finland, Norway, and Sweden (Kotiranta et al., 2009; Artsdatabanken, 2019; Artfakta..., 2019), but in Russian Karelia, is found only in the middle boreal zone (KRUTOV et al., 2014).

${ }^{*}$ Hypochnicium albostramineum (Bres.) Hallenb. - Pechenga District, in the vicinity of Sputnik settlement, near Santayarvi Lake, $69.51149^{\circ} \mathrm{N}$, $31.34935^{\circ} \mathrm{E}$, birch forest with a Cornus suecica and Empetrum sp. in ground vegetation layer, on the dead wood of Betula sp., 4 September 2018, coll. and id. SV (LE 314164).

Distribution in Fennoscandia: the species is not rare in the boreal zone of Finland (KotiRANTA et al., 2009; KuntTu et al., 2016), Norway, and Sweden (BERNICCHIA \& GORJón, 2010) and has been observed in Russian Karelia (RUOKOLAINEN \& KotKova, 2016b) and the Leningrad Region (KotKova, 2015). In Finland, it has been registered in the northern boreal zone in the Kevo Strict Nature Reserve (KotIRANTA \& SHIRYAEV, 2013).

${ }^{*}$ Lentaria afflata (Lagger) Corner - Pechenga District, the Pasvik State Nature Reserve, Varlama
Island, $69.140556^{\circ} \mathrm{N}, 29.249167^{\circ} \mathrm{E}$, on a piece of pine bark, coll. and id. YuK, 6 September 2018 (INEP 2045).

Distribution in Fennoscandia: this is the northernmost locality of the fungus in Fennoscandia. The species is widespread in the south of Scandinavia, but is not found in the northern boreal zone in Finland, Norway, Sweden or Russian Karelia (ARTSDAtabanken, 2019; ArtFakTa..., 2019; Kotiranta et al., 2009; KRUTOV et al., 2014). Northernmost known find in Norway is in Nordland, Brønnøy, Grønlidalen at $65.3565^{\circ} \mathrm{N}, 12.572^{\circ} \mathrm{E}$ (https://www.gbif.org/ occurrence/199054973). This fungus is classified in Category 4 DD in the Red Data Book of Karelia (Ivanter \& Kuznetsov, 2007).

${ }^{*}$ Lentaria micheneri (Berk. et M.A.Curtis) Corner - Pechenga District, the Pasvik State Nature Reserve, $69.2957^{\circ} \mathrm{N}, 29.487^{\circ} \mathrm{E}$, on mosses and litter under pines and birches, 25 September 1998, coll. and id. ASh (SVER 72030); Kandalaksha District, in the vicinity of Alakurtti settlement, $66.99^{\circ} \mathrm{N}$, $30.368889^{\circ} \mathrm{E}$, on the soil and litter in a mixed pinedominated forest, 4 September 2005, coll. E. V. Panov, id. ASh (SVER 73376).

Distribution in Fennoscandia: relatively widespread, but most observations have been made along the Norway Sea coast. The northernmost locality is in Finnmark, Alta Municipality, Eibyelva v/Jøraholmen, $69.9016^{\circ} \mathrm{N}, 23.2559^{\circ} \mathrm{E}$, in Alnus incana and Salix spp. bushes(https://www.gbif.org/occurrence/199055541). The species is quite widespread in Finland, but is less common in the north (KoTIRANTA et al., 2009). In Russian Karelia, it has only been found in the middle boreal subzone (SHIRYAEV, 2014).

Odontia fibrosa (Berk. et M.A. Curtis) Kõljalg Pechenga District, the Pasvik State Nature Reserve, $69.35237^{\circ} \mathrm{N}, 29.80826^{\circ} \mathrm{E}$, herb-rich birch forest with a willow admixture, on the bark of dry-standing juniper, 5 September 2018, coll. and id. SV (LE 314087).

Distribution in Fennoscandia: widespread in the south of the region (KoTIRANTA et al., 2009; GBIF, 2019), the find in the Murmansk Region is the northernmost in Fennoscandia. Previously, this species had been listed as present in the Murmansk Region by KõLJALG (1996) based on a specimen collected in the Botanical Garden (northern boreal part of the region) by an expedition of 
Estonian researchers in 1958 (EELURIKKUS, 2019). In Finland, the northern distribution of this species is limited to the middle boreal zone (KoTIRANTA et al., 2009). In Norway, this fungus is found mainly in the south, the currently northernmost observation was made in 2011 in Nordland County, $65.557572^{\circ} \mathrm{N}, 13.880452^{\circ} \mathrm{E}$ (https://www.gbif.org/occurrence/1424524835).

${ }^{*}$ Peniophorella pallida (Bres.) K.H. Larss. Kola District, near Pajyavr Lake, 69.17742 ${ }^{\circ} \mathrm{N}$, $32.20691^{\circ} \mathrm{E}$, birch forest with a Vaccinium myrtillus and Cornus suecica ground vegetation layer, on branches of dead standing Juniperus communis, 2 September 2018, coll. and id. SV (LE 314089).

Distribution in Fennoscandia: quite common in Finland, Norway and Sweden (KotiRAnTA et al., 2009; BERNICCHIA \& GORJÓN, 2010; https://www.gbif. org), but is more frequently found in the southern areas. In Norway, it is found at a latitude of $70^{\circ} \mathrm{N}$ (https://www.gbif.org). Findings from the middle taiga forests of the Leningrad Region are known (ZMiтROVICH et al., 2015). This species has not yet been found in Russian Karelia.

Phaeoclavulina flaccida (Fr.) Giachini - Kandalaksha District, in the vicinity of Alakurtti settlement, $66.992^{\circ} \mathrm{N}, 30.376^{\circ} \mathrm{E}$, on fallen needles in a mixed pine-dominated forest, 4 September 2005, coll. Panov E. V., id. ASh (SVER 74122).

Distribution in Fennoscandia: widespread and common in the southern part, but relatively rare in the north. In the Murmansk Region and Karelia, this species has been mentioned by KRUTOV \& SHUBIN (1979), but without an exact indication of the coordinates in both regions. In Karelia, it has recently been recorded in the Kivach Nature Reserve (SHIRYAEV \& Ruokolainen, 2017). In Finland, the species is found south of the northern boreal zone (KoTIRANTA et al., 2009); in Norway, it is also mainly found in the south, but reaches the latitudes at $69.8515^{\circ} \mathrm{N}$ (https://www. gbif.org/occurrence/199059071).

*Piloderma lanatum (Jülich) J. Erikss. et Hjortstam - Pechenga District, the Pasvik State Nature Reserve, in the vicinity of Glukhaya Plotina, $69.358667^{\circ}$ $\mathrm{N}, 29.791417^{\circ} \mathrm{E}$, pine forest, on dead Juniperus communis, 5 September 2018, coll. YK, id. IZ \& YK (INEP 2088); $69.35237^{\circ} \mathrm{N}, 29.80826^{\circ} \mathrm{E}$, herb-rich birch forest with a willow admixture, on the bark of a standing Juniperus communis snag, 5 September 2018, coll. and id. SV (LE 314092).

Distribution in Fennoscandia: sporadically distributed in Europe, and is rare everywhere, including Finland and Norway (ARtSdatabanKen, 2019; Kotiranta et al., 2009; Kotiranta \& Shyriaev, 2013; Kunttu et al., 2015). Previously, it has not been found in Russian Karelia (ZMitrovich, 2008). There are fewer than a dozen finds of this species in Norway; the northernmost find is in Nordland.

*Postia rennyi (Berk. et Broome) Rajchenb. the Murmansk Region, Murmansk, Semenovskoe Lake park, a group of planted deciduous trees, $68.991223^{\circ} \mathrm{N}, 33.097606^{\circ} \mathrm{E}$, on a log at the base of an old pillar, 28 September 2018, coll. YuK, id. IZ \& YuK (INEP 2093).

Distribution in Fennoscandia: a widespread species found in the central part of Russian Karelia (KRUTOV et al., 2014). In Finland, the fungus is rather common, but does not reach the northern borders of the country (KotiRANTA et al., 2009). In the north of Norway, it is rare (ARTSDATABANKEN, 2019), in Nordkapp, one specimen has been collected at a latitude of $71^{\circ} \mathrm{N}$ (https://www.gbif.org/occurrence/1229531515), but no information about the substrate is available.

${ }^{*}$ Pseudotomentella umbrina (Fr.) M.J. Larsen Pechenga District, in the vicinity of Sputnik settlement, near Santayarvi Lake, 69.50800 N, 31.34758 ${ }^{\circ}$ E, birch forest with a Cornus suecica and Empetrum sp. ground vegetation layer, on dead wood of Betula sp., 4 September 2018, coll. and id. SV (LE 314167).

Distribution in Fennoscandia: this ectomycorrhizal species has been collected in Finland, Norway, Sweden (Svantesson et al., 2019). It has recently been segregated from the Psedotomentella tristis complex, and herbarium specimens of this species need revision in order to better understand the range of $P$. umbrina in Fennoscandia.

Pterula sclerotiicola Berthier - Kirovsk District, in the vicinity of Kirovsk, Umetsky Pole, $67.652824^{\circ} \mathrm{N}, 33.678722^{\circ} \mathrm{E}$, old, overgrown aconite patch, dead stems of Aconitum septentrionale Koelle, 13 September 2018, coll. and id. ASh (AGS 905-18); ibidem, coll. YuK, id. ASh (INEP 2120). 
Distribution in Fennoscandia: relatively widespread in the boreal zone of Eurasia (SHIRYAEV, 2014). In the north of Europe, it is very seldom found in the subalpine belt of Scandinavia, the Khibiny Mts., and in the North Urals (KNUdSEn \& Vesterholt, 2012; SHIRYAEV, 2014), where it grows on the rotten parts of tallherbs and ferns. It has been found in natural conditions in the Lapland Nature Reserve, on the remains of Aconitum septentrionale. Present find is from a mountain valley, whereas all previous observations in Northern Fennoscandia have been made in mountains (КнгмICH et al., 2017). In Norway, in 1969, several specimens of this species were collected near Oslo in Akershus County at $59^{\circ} \mathrm{N}$ (GBIF, 2019); in 2006, it was found further north, in Sør-Trøndelag at $63.2024^{\circ} \mathrm{N}$.

${ }^{*}$ Ramariopsis crocea (Pers.) Corner - 1) Pechenga District, in the vicinity of Liinakhamari settlement, close to Trifonovo Lake, $69.638139^{\circ} \mathrm{N}, 31.273889^{\circ} \mathrm{E}$, at the foot of a hill in the birch forest on the soil in tall grass, 7 September 2018, 7 September 2019, coll. and id. ASh (AGS 763-18; INEP 2457); 2) Kirovsk District, Khibiny Mts., moraine at the foot of Kukisvumchorr Mt. in the valley of Maly Vud yavr Lake, $67.665225^{\circ} \mathrm{N}, 33.657106^{\circ} \mathrm{E}$, birch shrub-green moss forest, on the soil, 13 September 2018, coll. and id. ASh (AGS 901-18); 3) Kirovsk District, Khibiny Mts., southwest slope of the Poachvumchorr Ridge, $67.672222^{\circ} \mathrm{N}, 33.623^{\circ} \mathrm{E}$, birch forest, on the soil, 10 September 2019, coll. YuK, id. ASh (INEP 2440); 4) Kirovsk District, Khibiny Mts., Yuzhnoe Skvoznoe Gorge, $67.598917^{\circ} \mathrm{N}, 33.595417^{\circ} \mathrm{E}$, timberline, in fern thickets (Athyrium distentifolium), on the soil, 11 September 2019, coll. and id. YuK (INEP 2441, 2456); Yuzhnoe Skvoznoe Gorge, 67.596861 $\mathrm{N}$, $33.5905^{\circ} \mathrm{E}$, aspen forest, on the soil, 11 September 2019, coll. and id. YuK (INEP 2455).

Distribution in Fennoscandia: widespread in the southern part, but rare in the north. Ramariopsis crocea was found in the Kivach State Nature Reserve in September 2016 (Shiryaev \& Ruokolainen, 2017), in the middle boreal subzone of Russian Karelia, but before that never in Karelia. During our fieldwork at the same location in the Murmansk Region, we have not found this species (ShIRYAEv, 2013). In recent years, it has been observed in the northern boreal zone of Finland (KuntTu et al., 2014). In Norway, this fungus occurs up to $69^{\circ} \mathrm{N}$ in the county of Troms, Storfjord municipality, Signaldalen, Paras (https://www.gbif.org/occurrence/1324361666).

"Ramariopsis tenuicula (Bourdot et Galzin) R.H. Petersen (incl. Clavulinopsis minutula Bourd. et Galz.) - 1) Pechenga District, in the vicinity of Liinakhamari settlement, in the vicinity of Trifonovo Lake, at the foot of a hill on the soil in the meadow, $69.638139^{\circ} \mathrm{N}, 31.273889^{\circ} \mathrm{E}$, tall-herb birch forest, on the soil, 7 September 2018, 7 September 2019, coll. and id. ASh (AGS 824-18; INEP 2458); 2) Kirovsk District, Khibiny Mts., Yuzhnoe Skvoznoe Gorge, $67.597639^{\circ} \mathrm{N}, 33.592056 \mathrm{E}$ and $67.598056^{\circ} \mathrm{N}, 33.592889^{\circ} \mathrm{E}$, mixed forest, on the soil, 11 September 2019, coll. YuK, id. ASh (INEP 2459, 2460).

Distribution in Fennoscandia: relatively widespread in the south, from broadleaf forests to the southern boreal zone, less frequently found in the north (SHIRYAEV, 2104; GBIF, 2019). In Norway, this species has been found in Nordland, Rana, Ørtfjellmoen bro, $66.4025^{\circ} \mathrm{N}, 14.6642^{\circ} \mathrm{E}$ (https://www. gbif.org/occurrence/199050737); in Finland, in the middle taiga zone and once in the northern taiga zone (A. Shiryaev, unpublished data). This species has not yet been found in Russian Karelia. In the Murmansk Region, it has been found in two locations, in both it produced a large number of fruiting bodies. The location in Pechenga District is the northernmost in Fennoscandia.

Ramariopsis tenuiramosa Corner - 1) Pechenga District, the Pasvik State Nature Reserve, area adjacent to Varlama Island, $69.139591^{\circ} \mathrm{N}, 29.245635^{\circ} \mathrm{E}$, meadow, on the soil, 6 September 2018, coll. and id. ASh (INEP 2044); 2) Kandalaksha District, in the vicinity of Alakurtti settlement, $66.992^{\circ} \mathrm{N}, 30.376^{\circ} \mathrm{E}$, on the soil at the forest-meadow boundary, 27 September 1998, coll. and id. ASh (SVER 73378).

Distribution in Fennoscandia: most of the records have been found in the southern part, while in the north boreal zone the species is relatively rare (Kotiranta, 2009; GBIF, 2019). Previously, the species has been reported in a single location in the Murmansk Region in Ivanovka Bay (ShIRYAEv, 2013). This fungus was found in the Kivach State Nature Reserve in September 2016 (ShiRYAev \& RuokolainEN, 2017), in the middle boreal subzone of Russian 
Karelia. In Finland, it is found mainly in the south, but there are finds in the northern boreal zone in the Kevo Strict Nature Reserve (Kotiranta \& Shiryaev, 2013). In Norway, the northernmost observation of Ramariopsis tenuiramosa is at a latitude of $65^{\circ} \mathrm{N}$ (ARTSDATABANKEN, 2019).

*Sarcodon scabrosus (Fr.) P. Karst. - Pechenga District, on the bank of the downstream reaches of the Nautsi River, $68.915341^{\circ} \mathrm{N}, 28.991631^{\circ} \mathrm{E}$, pine forest, on the soil, 13 September 2016, YuK (INEP 2395).

Distribution in Fennoscandia: widespread in the boreal forests in Finland and Norway, but is less common in the northern boreal zone (KotIRANTA et al., 2009; Artsdatabanken, 2019). In Norway, this fungus was found in 2010-2016 in the area bordering the Russia's Pechenga District (Artsdatabanken, 2019). In Russian Karelia, it is not found north of the middle boreal zone (KRUTOV et al., 2014).

"Sistotrema diademiferum (Bourdot et Galzin) Donk - Pechenga District, the Pasvik State Nature Reserve, in the vicinity of Gluhaya Plotina, $69.366257^{\circ} \mathrm{N}$, $29.743689^{\circ} \mathrm{E}$, on the compacted soil, 2 September 2016, coll. EB, id. IZ \& YuK (INEP 2127).

Distribution in Fennoscandia: quite common in Sweden, in Norway it is found mainly in the south; there is a single find in Troms County, and there are several finds in Finland (ARTSDATABANKEN, 2019; ARTFAKTA..., 2019; KotiRANTA et al., 2009). According to the recent data, the number of finds of this species has increased in Finland (KunTtu et al., 2018), but it has not yet been reported in the northern boreal zone. This species has not yet been found in Russian Karelia.

Tomentellopsis echinospora (Ellis) Hjortstam Pechenga District, in the vicinity of Sputnik settlement, near Santayarvi Lake, 69.50303 ${ }^{\circ} \mathrm{N}, 31.33786^{\circ} \mathrm{E}$, forest-tundra, birch forest with a Cornus suecica and Empetrum sp. ground vegetation layer, on a fallen $\mathrm{Al}$ nus incana stem, 4 September 2018, coll. and id. SV (LE 314169); ibidem, on a wooden pole, 4 September 2018, coll. and id. YuK (INEP 2287).

Distribution in Fennoscandia: in the Murmansk Region, this species has recently been observed in the Pasvik State Nature Reserve in the boreal zone (Кнімісн \& Zмiтrovich, 2019). We found Tomentellopsis echinospora in forest-tundra for the first time.
The fungus is known from Russian Karelia (KRUTOV et al., 2014). This species is widespread in Finland (Kotiranta et al., 2009) and occurs mainly in southern Norway, except for the find in 1976 in the north of the country (Øvre Pasvik National Park), near the border with Russia (ARTSDATABANKEN, 2019).

Tulasnella allantospora Wakef. \& A. Pearson Pechenga District, in the vicinity of Sputnik settlement, near Lake Santayarvi, $69.50800^{\circ} \mathrm{N}, 31.34758^{\circ} \mathrm{E}$, birch forest with a Cornus suecica and Empetrum sp. ground vegetation layer, on Betula sp. dead wood, 4 September 2018, coll. and id. SV (LE 314166).

Distribution in Fennoscandia: species has been found in five localities in Finland (KotiRAnTA et al., 2009; Kunttu et al., 2018) and once in the Murmansk Region over 50 years ago (RAITVIIR, 1967). In Norway, this fungus is found at a latitude of $64^{\circ} \mathrm{N}$, in Sweden at $65^{\circ} \mathrm{N}$ (https://www.gbif.org). There are no data on observations of the species in Russian Karelia.

${ }^{*}$ Typhula curvispora (Corner) Berthier - Kirovsk District, Polar-Alpine Botanical Garden-Institute, $67.648113^{\circ} \mathrm{N}, 33.669761^{\circ} \mathrm{E}$, in the nursery garden, on dead stems of Polygonum weyrichii Fr. Schmidt, 9 September 2018, coll. YuK, id. ASh (INEP 2123).

Distribution in Fennoscandia: appears to be more common in Asia, prefers mountain and seashore habitats, where it develops on tall herbs (CoRNER, 1970; Shiryaev, 2014). In Europe, only one specimen is known from Belarus, Bialowieza National Park, found on the introduced Polygonum sp. in the vicinity of Kamenyuki village (A. Shiryaev, unpublished data). This species has never been found in Russian Karelia, Sweden, Norway or Finland. In the Murmansk Region, it has only been found in the Botanical Garden on introduced plants. The species' taxonomical position is doubtful, different authors treat this species as separate species in Typhula or include it in Pistillaria petasitis S. Imai or Pistillaria petasitis var. curvispora Corner.

* Typhula pachypus Berthier-Kirovsk District, Polar-Alpine Botanical Garden-Institute, $67.648113^{\circ} \mathrm{N}$, $33.669761^{\circ} \mathrm{E}$, in the nursery-garden, on the old dead stems of Heracleum sosnowskyi Manden, 9 September 2018, coll. YuK, id. ASh (INEP 2122).

Distribution in Fennoscandia: found in the west- 
ern, central and eastern Europe. The largest number of samples has been reported in nemoral and hemiboreal forests as well as in mountainous areas on fallen dead twigs and tall herbs (Berthier, 1976; Shiryaev, 2014). Not found in Sweden, Norway, Finland and Russian Karelia Republic. In the Murmansk Region, it has only been found in the Botanical Garden on introduced plants. The closest known observation of the species is $900 \mathrm{~km}$ to the south, in the Leningrad Region, Russia (SHIRYAEv, 2013).

${ }^{*}$ Typhula struthiopteridis Corner - Kirovsk District, Polar-Alpine Botanical Garden-Institute, $67.648113^{\circ} \mathrm{N}, 33.669761^{\circ} \mathrm{E}$, in the nursery garden, on the dead fronds of the fern Matteuccia struthiopteris (L.) Tod, 9 September 2018, coll. and id. ASh (INEP 2121).

Distribution in Fennoscandia: probably common everywhere where the ostrich fern is found. At the moment, most $T$. struthiopteridis finds are known in Siberia, from where (Altai), it was described (CoRNER, 1970). Several finds of this species are known in the south of Finland (ShiRYAEv, 2008; KotiRAnta et al., 2009). There are also reports of observations in Sweden at a latitude of $62^{\circ} \mathrm{N}$ (https://www.gbif.org/ occurrence/1086399572). Our find in the Murmansk Region is the northernmost in Fennoscandia. Fungi associated with Matteuccia struthiopteris have not been studied in the Murmansk Region in natural fern populations. This fern has been listed on the Red Data Book of the Murmansk Region as a species requiring special attention to its status (Konstantinova et al., 2014). It is sporadically found in the Murmansk Region (RAMENSKAYA, 1983). It is possible that Typhula struthiopteridis may appear to be more common in the region.

\section{DISCUSSION}

Twenty-one species of aphyllophoroid fungi were reported as new findings in the Murmansk Region. One of the reasons for the new finds is an increase in the number of field studies and under-recording of the mycobiota of the Murmansk Region in the past. Some types of fungi require special attention due to the size of the fruiting body and the specific habitat. Especially, this applies to the small fruiting bodies of the genus Ceratellopsis, which are incon- spicuous unless specifically looked for. On the other hand, changes in climatic conditions may contribute to the spread of some species to the north. The localities of six fungi species (Ceratellopsis corneri, Ceratellopsis sagittiformis, Hydnomerulius pinastri, Odontia fibrosa, Tulasnella allantospora, Typhula struthiopteridis) are currently the northernmost in Fennoscandia.

For most of the species listed in this paper, only a few localities are currently known in the Murmansk Region. Five species (Ceratellopsis corneri, Fibulomyces mutabilis, Lentaria afflata, Piloderma lanatum, Sistotrema diademiferum) are currently known only in the Pasvik State Nature Reserve.

Postia rennyi was found in an urban area on an anthropogenic substrate. This species may occur in the forests of the Murmansk Region, in contrast to the fungi associated with introduced plants. The two species observed by us in the Botanical Garden $-T y$ phula curvispora and Typhula pachypus - were confined to introduced plants and can hardly be found in the natural forests. Such fungi are present only in urban areas with a suitable substrate. Typhula pachypus grows on Heracleum sosnowskyi, which is a very aggressive invasive plant species (Borovichev \& VRONSKIJ, 2020). Heracleum species are widespread into the territory of Norway, and Typhula pachypus is likely to be discovered soon in this country, too (Alm \& Often, 2006; Meier et al., 2017).

One of the listed here species is included in the Red Book of Karelia: Lentaria afflata (DD). Clavaria amoenoides, Clavaria flavipes, Ramariopsis crocea are listed in the category VU, and Clavulinopsis umbrinella, Sarcodon scabrosus in the category NT in the Norwegian Red List (BRANDRUd, 2015). According to the Red List, these rare species are found mainly in the south; however, some of the species reach Nordland County, and more northern finds have already been reported in contemporary information systems. In the Khibiny Mts., in Yuzhnoe Skvoznoe Gorge, where we found Clavulinopsis umbrinella, Ramariopsis crocea and Ramariopsis tenuicula, the protected area "Yuzhnoe Skvoznoe Gorge" is projected. In addition to fungi, numerous rare plant species have been found in this gorge.

Some of the species may have appeared in the region due to the combined effects of the anthropogenic factor and the current climate warming in the Arctic. The pro- 
motion of species such as Clavaria amoenoides, Ramariopsis crocea, Clavaria flavipes in the northern boreal zone of the Murmansk Region is similar to the trend of their spreading to the north in Finland in the past ten years (KunTtu et al., 2014, 2016, 2018).

Since long-term monitoring of large areas of forest is hardly possible, it is difficult to say whether the species have arrived in a given area or simply have become more frequent. Climate change may have contributed not only to the northward spreading of certain species, but also to an increase in their frequency.

\section{ACKNOWLEDGEMENTS}

We thank Dr Eugene Borovichev for collecting the specimen of Sistotrema diademiferum and valuable comments; Dr Ivan Zmitrovich for his help in identifying some of the specimens; Olga Petrova for preparing the map. We highly appreciate the help of Dr Natalia Polikarpova in organizing fieldwork at the Pasvik State Nature Reserve. The study was conducted as part of a project supported by the Russian Foundation for Basic Research (grant no. 18-0500398 A). The study by YuK was carried out as part of an institutional research project (no. AAAA-A18118021490070-5) by the Institute of the Industrial Ecology Problems of the North at the Kola Science Centre, RAS. The study by SV was carried out as part of the institutional research project by the Komarov Botanical Institute (AAAA-A19-119020890079-6).

\section{REFERENCES}

Анti T., Hämet-Ahti L., Jalas J., 1968: Vegetation zones and their sections in NorthernWestern Europe. - Annales Botanici Fennici, 5: 169-211.

Alisov B.P., 1969: Klimat SSSR. - Moscow. [In Russian]

Alm T., Often A., 2006: Tromsøpalmen og dens slektninger - et knippe pestplanter. -Ottar, 261: 10-17. [In Norwegian]

Artfakta. Artdatabanken. https://artfakta.artdatabanken.se [Accessed: 15.05.2019].

ARTSDATABANKEN. https://artsdatabanken.no [Accessed 30.05.2019].

Bernicchia A., GorJón S.P., 2010: Corticiaceae s.l. Fungi Europaei, 12. - Alassio.
Berthier J., 1976: Monographie des Typhula Fr., Pistil-laria Fr. et genres voisins. - Bulletin mensuel de la Société linnéenne de Lyon, 45: 1-233.

Bolshakov S.Yu., Potapov K.O., Ezhov O.N., VoLobuev S.V., Кнimich Yu.R., Zmitrovich I.V., 2016: New species for regional mycobiotas of Russia. 1. Report 2016. - Mikologija i Fitopatologija, 50(5): 275-286.

Bolshakov S.Yu., Volobuev S.V., Potapov K.O., Shiryaev A.G., Shiryaeva O.S., Ezhov O.N., Rebriev Yu.A., Palamarchuk M.A., Khimich Yu.R., Borovichev E.A., Zmitrovich I.V., 2018: New species for regional mycobiotas of Russia. 3. Report 2018. - Mikologija i Fitopatologija, 52(6): 386-397.

Bondartseva M.A., Krutov V.I., Lositskaya V.M., Yakovlev E.B., Skorokhodova S.B., 2001: Griby zapovednika "Kivach" (Annotirovannyj spisok vidov). - Moscow. [In Russian]

Bondarceva M.A., Parmasto E.H., 1986: Opredelitel' gribov SSSR. Porjadok afilloforovye, 1. Leningrad. [In Russian]

Borovichev E.A., Vronskij N.V. (eds.), 2020: Priroda i korennoe naselenie Arktiki pod vlijaniem izmenenija klimata i industrial'nogo osvoenija: Murmanskaja oblast'. - Moscow. [In Russian]

Brandrud T.E., 2015: Sopper (Fungi). Norsk rødliste for arter 2015. Artsdatabanken. http://www.artsdatabanken.no/Rodliste/Artsgruppene/Sopper [Accessed 30.10.2019]

Corner E.J.H., 1970: Supplement to "A monograph of Clavaria and allied genera". - Nova Hedwigia, 33: 1-299.

Dahlberg A., Bultmann H., 2013: Fungi, 10. Arctic Biodiversity Assessment. Status and trends in Arctic biodiversity. - Akureyri.

EELURIKKUS. https://elurikkus.ee/en/collections/fungal [Accessed 15.05.2019].

GBIF. https://www.gbif.org/ [Accessed 11.06.2019].

InDEX Fungorum. CABI Database. http://www.indexfungorum.org [Accessed 30.05.2019].

IsAeva L.G., Kнімісн Y.R., 2011: Catalogue of aphyllophoroid fungi of Murmansk Region. - Apatity. [In Russian]

Ivanter E.V., KuzNetsov O.L. (eds), 2007: Red Data Book of Republic Karelia. - Petrozavodsk. [In Russian]

Kнімісн Yu.R., 2013: Afilloforoidnye griby na 
drevesnyx introducentax zelenyx nasaždenij goroda Apatity. - Vestnik MGTU, 16: 526-529. [In Russian]

Khimich Y.R., Zmitrovich I.V., Ruokolainen A.V., 2015: Aphyllophoroid fungi of the "Pasvik" State Nature Reserve (Murmansk Region). - Mikologija i Fitopatologija, 49(4): 234-241. [In Russian]

Khimich Yu.R., Kotiranta H., Borovichev E.A., 2016: New findings of aphyllophoroid fungi in the Murmansk Region. 1. Urbanized territories. Trudy Karelskogo Naučnogo Centra, 7: 100-105. [In Russian]

Kнiмich Y.R., Zмiтrovich I.V., 2017: The first confirmed finding of Leptosporomyces mundus (Basidiomycota) in Russia. - Folia Cryptogamica Estonica, 54: 59-62.

Khimich Yu.R., Shiryaev A.G., Isaeva L.G., BerliNA N.G., 2017: Ground-dwelling aphyllophoroid fungi of the Lapland Reserve. - Trudy Karelskogo Naučnogo Centra, 1: 50-61. [In Russian]

Kнiмich Yu.R., Zmitrovich I.V., 2019: New findings of aphyllophoroid fungi in the Murmansk Region. 2. Pechengsky District. - Trudy Karelskogo Naučnogo Centra, 1: 93-100.

Knudsen H., Vesterholt J. (eds), 2012: Funga Nordica. Agaricoid, boletoid, clavarioid, cyphelloid and gastroid genera. Nordsvamp. - Copenhagen.

Konstantinova N.A., Koryakin A.S., MaKaroVA O.A., BiAnKi V.V. (eds), 2014: Red data Book of the Murmansk Region. 2nd edition. - Kemerovo. [In Russian]

Kotiranta H., SaArenoksa R., Kytövuori I., 2009: Aphyllophoroid fungi of Finland. A check-list with ecology, distribution, and threat categories. - Norrlinia, 19: 1-223.

Kotiranta H., Shiryaev A., 2013: Notes on Aphyllophoroid fungi (Basidiomycota) in Kevo, collected in 2009. - Kevo Notes, 14: 1-22.

Kotкova V.M., 2015: New data on aphyllophoraceous fungi of the protected areas of the Leningrad Region. VII. Planned protected areas of the Vyborg District. - Novosti sistematiki niz ix rastenij, 49: 161-176. [In Russian]

KõLJalg U., 1996: Tomentella (Basidiomycota) and related genera in Temperate Eurasia. - Oslo.

Krutov V.I., Shubin V.I., Predtechenskaya O.O., Ruokolainen A.V., Kotkova V.M., Polevoi A.V., Khumala A.E., Yakovlev E.B., 2014: Griby i nasekomye - konsorty lesoobrazuju čix drevesnyx porod Karelii. - Petrozavodsk. [In Russian]

Kunttu P., Juutilainen K., Helo T., Kuluu M., KeKKi T., Kotiranta H., 2018: Updates to Finnish aphyllophoroid funga (Basidiomycota): new species and range extensions. - Mycosphere, 9(3): 519-564.

Kunttu P., Kuluu M., Kekki T., Pennanen J., Savola K., Helo T., Kotiranta H., 2016: Extensions of known geographic distribution of aphyllophoroid fungi (Basidiomycota) in Finland. - Mycosphere, 7(3): 333-357.

Kunttu P., Kuluu M., Kotiranta H., 2012: New national and regional biological records for Finland 2. Contributions to the Finnish aphyllophoroid funga (Basidiomycota). - Memoranda Societatis pro Fauna et Flora Fennica Fauna Flora Fennica, 88: 61-66.

Kunttu P., Kulju M., Kotiranta H., 2015: Contributions to the Finnish aphyllophoroid funga (Basidiomycota): new and rare species. - Czech Mycology, 67(2): 137-156.

Kunttu P., Kulju M., Pennanen J., Kotiranta H., Halme P., 2011: Additions to the Finnish aphyllophoroid fungi. - Folia Cryptogamica Estonica, 48: 25-30.

Kunttu P., Pennanen J., Helo T., Kulju M., SöderHoLm U., 2013: New national and regional biological records for Finland 4. Additions to the knowledge of Finnish aphyllophoroid funga (Basidiomycota). - Memoranda Soc. Fauna Flora Fennica, 89: 119-124.

Kunttu P., Pennanen J., Kekri T., Kuluu M., SuomINEN M., 2014: Noteworthy records of aphyllophoroid fungi in Finland (Basidiomycota). - Acta Mycologica, 49(2):221-235.

Meier S., Taff G.N., Aune J.B., Eiter S., 2017: Regulation of the Invasive plant Heracleum persicinum by private landowners in Tromsø, Norway. - Invasive Planta Science and Management, 10: 166-179.

Melekhin A.V., Davydov D.A., Borovichev E.A., Shalygin S.S., Konstantinova N.A., 2019: CRIS - service for input, storage and analysis of the biodiversity data of the cryptogams. - Folia Cryptogamica Estonica, 56: 99-108.

Moen A., 1999: National Atlas of Norway: Vegetation. - Norwegian Mapping Authority, Hønefoss. 
Ohenoja E., Kaukonen M., Ruotsalainen A.L., 2013. Sarcosoma globosum - an indicator of climate change? - Acta Mycol, 48(1): 81-88.

RAITVIIR A., 1967: Opredelitel' geterobazidial'nyx gribov (Heterobasidiomycetidae) SSSR / Ed. E. H. Parmasto. - Leningrad. [In Russian]

RAMENSKAya M.L., 1983: Analiz flory Murmanskoj oblasti i Karelii. - Leningrad. [In Russian]

Ruokolainen A.V., Kotkova V.M., 2016a: New and rare for the Republic of Karelia species of aphyllophoroid fungi (Basidiomycota). - Trudy Karelskogo Naučnogo Centra, 3: 90-96. [In Russian]

Ruokolainen A.V., Kotkova V.M., 2016b: New and rare for the Republic of Karelia species of aphyllophoroid fungi (Basidiomycota). II. - Trudy Karelskogo Naučnogo Centra, 7: 93-99. [In Russian]

Shiryaev A.G., 2008: New and rare clavarioid fungi from the hemiboreal zone of Finland. - Karstenia, 48(1): 29-32.

Shiryaev A.G., 2013: The clavarioid mycobiota of northern Fennoscandia: is it a tundra or a boreal structure? - Trudy Karelskogo Naučnogo Centra, 2: 55-64. [In Russian]

Shiryaev A.G., 2014: Prostranstvennaja differenciacija bioty klavarioidnyx gribov Rossii: ecologogeografičeskij aspect. Dissertacija doctora biologičeskix nauk. - Moscow. [In Russian]

Shiryaev A.G., Ruokolainen A.V., 2017: Clavarioid fungi of the Kivach Strict Nature Reserve: changes in the diversity of the middle boreal mycobiota along longitudinal gradient. - Trudy Karelskogo
Naučnogo Centra, 6: 48-60. [In Russian]

Shubin V.I., Krutov V.I., 1979: Griby Karelii i Murmanskoi oblasti (ekologo-sistematičeskij spisok). - Leningrad. [In Russian]

Svantesson S., Larsson K.-H., Kõlualg U., May T.W., Cangren P., Nilsson R.H., Larsson E., 2019: Solving the taxonomic identity of Pseudotomentella tristis s.1. (Thelephorales, Basidiomycota) - a multi-gene phylogeny and taxonomic review, integrating ecological and geographical data. - MycoKeys, 50: 1-77.

Svetasheva T.Yu., Arslanov S.N., Bolshakov S.Yu., Volobuev S.V., Ivanov A.I., Potapov K.O., Ezhov O.N., Khimich Yu.R., Borovichev E.A., Rebriev Yu.A., SARkina I.S., IvolLOV A.V., Zmitrovich I.V., 2017: New species for regional mycobiota of Russia. 2. Report 2017. Mikologija i Fitopatologija, 51(6): 375-389.

Yakovlev B.A., 1961: Klimat Murmanskoj oblasti. Murmansk. [In Russian]

Zmitrovich I.V., 2008: Semejstva atelievye, korticievye. Opredelitel' gribov Rossii. Porjadok afilloforovye, 3. - Moscow - Sankt-Petersburg. [In Russian]

Zmitrovich I.V., Stolyarskaya M.V., Kalinovskaya N.I., Popov E.S., Myasnikov A.G., Morozova O.V., Volobuev S.V., Bolshakov S.Yu., Svetasheva T.Yu., Bondartseva M.A., KovaLENKO A.E., 2015: Macromycetes of the NizhneSvirsky Reserve (annotated checklist). - Saint Petersburg. [In Russian]

\section{İDOMŪS AFILOFOROIDINIŲ GRYBŲ RADINIAI ŠIAURĖS RYTINE்JE FENOSKANDIJO- JE (MURMANSKO REGIONAS, RUSIJA)}

\section{Yuliia R. Khimich, Anton G. Shiryaev, Sergey V. Volobuev}

\section{Santrauka}

Murmansko regione (šiaurès rytinė Fenoskandija, Rusija) aptiktos 28 ịdomios afiloforoidinių grybų rūšys. Dvidešimt viena rūšis: Ceratellopsis corneri, Clavaria amoenoides, C. flavipes, Clavulinopsis umbrinella, Fibulomyces mutabilis, Hydnomerulius pinastri, Hyphoderma sibiricum, Hypochnicium albostramineum, Lentaria afflata, L. micheneri, Peniophorella pallida, Piloderma lanatum, Postia rennyi, Pseudotomentella umbrina, Ramariopsis crocea,
R. tenuicula, Sarcodon scabrosus, Sistotrema diademiferum, Typhula curvispora, T. pachypus ir T. struthiopteridis nebuvo rasta iame regione. Septynios rūšys: Ceratellopsis sagittiformis, Odontia fibrosa, Phaeoclavulina flaccida, Pterula sclerotiicola, Ramariopsis tenuiramosa, Tomentellopsis echinospora ir Tulasnella allantospora iki šiol buvo žinomos tik vienoje ar dviejose radavietėse miškatundrès ir šiaurinèje borealinejje juostose. 